Firdaouss Bouisfi
PhD student
Moulay Ismail University
Faculty of sciences
Morocco
Achraf Bouisfi
PhD student
Moulay Ismail University
Faculty of sciences
Morocco
Hamza Ouarriche
PhD student
Moulay Ismail University
Faculty of sciences
Morocco
Mohamed El Bouhali
PhD student
Moulay Ismail University
Faculty of sciences
Morocco

\section{Improving Removal Efficiency of Sedimentation Tanks Using Different Inlet and Outlet Position}

Sedimentation by gravity is the oldest water treatment. Inlet and outlet of rectangular sedimentation tank are often located in the middle of the tank. The present investigation studies the effect of changing inlet and outlet position of rectangular sedimentation tank on removal efficiency using Computational Fluid Dynamics method. Two different configurations are proposed and they have been tested with varying particles diameters and concentration. Numerical model ability to describe flow field behaviour inside the tank is confirmed by an experimentation data. Results show that inlet and outlet position influence the flow field and removal efficiency of sedimentation tanks, especially for the case of fine particles (50 and $120 \mu \mathrm{m})$.

Keywords: Sedimentation, rectangular sedimentation tank; Computational Fluid Dynamics; Numerical model; Flow field; removal efficiency.

\section{INTRODUCTION}

Sedimentation by gravity is the oldest water treatment process that constitutes a mean part of any water treatment plant. The performance of sedimentation tanks is crucial such that can have a considerable effect on the rest of the plant. In irrigation network for example, drip emitters clogging are directly caused by water quality [1]. Many numerical models have been developed to study sedimentation tanks. Computational fluid dynamics (CFD) simulation is the most used as a design tool to optimize the majority of industrial process $[2,3]$. The first extensive study concerning CFD simulation of the flow field in sedimentation tank has been conducted by Larsen [4]. Few years later, Imam et al [5] simulated discrete particles in rectangular clarifiers using finite difference model. To account the turbulence, Shamber and Larock [6] solved the Navier-Stockes, k- $\varepsilon$ turbulence model and transport equation for suspended solid concentration to several secondary clarifiers.

In general, uniform flow allows suspended particles deposition. However, the inlet flow is widely turbulent; recirculation zones create regions with high turbulent intensity and reduce effective sedimentation volume of the tank. Consequently, removal efficiency is reduced. To overcome this problem, energy of incoming flow has to be dissipated, so many investigations proposed the use of baffles. Huggins et al [7] studied the effect of adding baffle on removal efficiency. It's found that effluent solids approximately reduced by $51 \%$. Goula et al [8] noticed that adding vertical baffle at the feed section of sedimentation tank in potable water treatment increases

Received: September 2018, Accepted: February 2019

Correspondence to: Bouisfi Firdaouss, PhD student

Moulay Ismail University, Faculty of sciences,

Meknes, Morocco.

Email: firdaous.bouisfi@gmail.com

doi:10.5937/fmet1904894B

(C) Faculty of Mechanical Engineering, Belgrade. All rights reserved solids removal efficiency from $90.4 \%$ to $98.6 \%$. Furthermore, the suitable baffle position has been the subject of several numerical and experimental investigations. It should be noted that the position of baffle is related to the flow field and the importance of buoyancy forces [9].

In the same context, some studies have been done on the optimization of inlet design and position in order to avoid dead zones formation. Bajcar et al [10] proved that vertical flow in circular settling tank is more efficient than horizontal flow in terms of removal efficiency, especially at high inlet suspension concentration. Rostami et al [11] simulated the flow field in rectangular clarifier with different inlet apertures and showed that increasing number of slots improve uniformity of the flow and decrease the size of circulation zone. The present paper studies numerically the effect of inlet and outlet position on the removal efficiency.

\section{THE CHARACTERISTICS OF THE TANKS}

In order to study the effect of inlet and outlet position on removal efficiency of sedimentation tank, the experimental setup of Kantoush et al [12] conducted by the Laboratory of Hydraulic Constructions of the Swiss Federal Institute of Technology is adopted. A schematic view of the experimental setup is illustrated in Figure 1.

The setup consists of rectangular inlet and outlet channel $0.25 \mathrm{~m}$ wide, a rectangular shallow basin with inner dimension of $6.0 \mathrm{~m}$ length, $4.0 \mathrm{~m}$ wide and $0.2 \mathrm{~m}$ depth. The flow rate is $0.007 \mathrm{~m}^{3} / \mathrm{s}$; the fluid density is 996 $\mathrm{kg} / \mathrm{m}^{3}$. The sediment concentration is $\mathrm{C}_{\mathrm{s}}=3 \mathrm{~kg} / \mathrm{m} 3$, the median grain size and sediment density are respectively $D_{50}=50 \mu \mathrm{m}$ and $\rho_{\mathrm{s}}=1500 \mathrm{~kg} / \mathrm{m}^{3}$. Furthermore, two modified geometries: (B) and (C) were formulated based on changing inlet and outlet position as illustrated in Fig 2. They have been tested with different particle diameter and concentration (Table 1). 


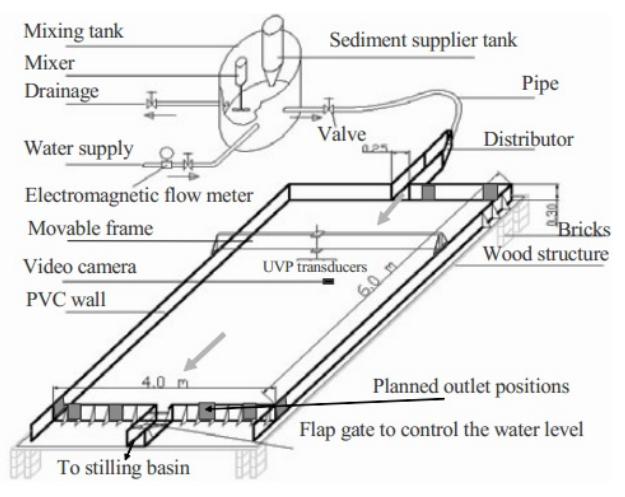

Figure 1 : Schematic view of experimental installation

The setup consists of rectangular inlet and outlet channel $0.25 \mathrm{~m}$ wide, a rectangular shallow basin with inner dimension of $6.0 \mathrm{~m}$ length, $4.0 \mathrm{~m}$ wide and $0.2 \mathrm{~m}$ depth. The flow rate is $0.007 \mathrm{~m}^{3} / \mathrm{s}$; the fluid density is $996 \mathrm{~kg} / \mathrm{m}^{3}$. The sediment concentration is $\mathrm{C}_{\mathrm{s}}=3 \mathrm{~kg} / \mathrm{m} 3$, the median grain size and sediment density are respectively $\mathrm{D}_{50}=50 \mu \mathrm{m}$ and $\rho_{\mathrm{s}}=1500 \mathrm{~kg} / \mathrm{m}^{3}$. Furthermore, two modified geometries: (B) and (C) were formulated based on changing inlet and outlet position as illustrated in Fig 2. They have been tested with different particle diameter and concentration (Table 1).

\section{MATHEMATICAL MODEL}

The rectangular sedimentation tank was modeled in $3 \mathrm{D}$ with a commercial CFD code, using finite volume discretization method. The flow behaviour in sedimentation tanks can be studied as multiphase flow using either Euler-Euler or an Euler-Lagrange approach. In this study Euler-Lagrange approach is adopted. Sediments are modeled as dispersed phase without particle-particle interaction since their volume fraction is below $10 \%$. This carried out with Discrete Phase Model (DPM) which tracks particles in Lagrangian reference frame and fluid phase is treated as a continuum. Moreover, particle-fluid interaction is taking into account using a coupled Discrete Phase Model (Two-way coupling).

\subsection{Eulerian phase}

The fluid flow is considered to be steady and incompressible. The fluid field equations governing in a sedimentation tank are as follows:

Continuity equation :

$$
\frac{\partial \overline{v_{i}}}{\partial x}=0
$$

Momentum equation:

$$
\begin{aligned}
& \frac{\partial \bar{v}_{i}}{\partial x_{j}}=-\frac{\partial \bar{P}}{\partial x_{i}}+\mu \frac{\partial}{\partial x_{j}}\left(\frac{\partial \bar{v}_{i}}{\partial x_{j}}+\frac{\partial \bar{v}_{j}}{\partial x_{i}}\right)- \\
& -\frac{\partial}{\partial x_{j}}\left(\rho \overline{v_{i}{ }^{\prime} v_{j}{ }^{\prime}}\right)
\end{aligned}
$$

where $\bar{v}_{i}$ is the average mean flow velocity, $\bar{P}$ is the averaged value of pressure, $\mu$ is dynamic viscosity and $\rho$ is the density of fluid. $s$ is the turbulent velocity fluctuation such that $v_{i}=\bar{v}_{i}+v_{i}^{\prime} . v_{i}$ is the instantaneous velocity in $x_{i}$ coordinate direction.
Table 1: investigated cases with different median grain size $D_{50}$ and sediment concentration $C_{s}$

\begin{tabular}{|c|c|c|}
\hline Case No. & $\mathrm{D}_{50}(\mu \mathrm{m})$ & $\mathrm{C}_{\mathrm{s}}(\mathrm{g} / \mathrm{l})$ \\
\hline 1 & 50 & 3 \\
\hline 2 & 50 & 10 \\
\hline 3 & 120 & 3 \\
\hline 4 & 120 & 10 \\
\hline 5 & 250 & 3 \\
\hline 6 & 250 & 10 \\
\hline 7 & 500 & 3 \\
\hline 8 & 500 & 10 \\
\hline
\end{tabular}

$\rho \overline{v_{i}{ }^{\prime} v_{j}{ }^{\prime}}$, the Reynolds Stress tensor, is determined with a turbulence closure model. In this study, Realizable k- $\varepsilon$ turbulence model was used to close the model since this model provides the best performance for separated flows. Transport equation for turbulent kinetic energy $\mathrm{k}$ and dissipation of turbulent kinetic energy $\varepsilon$ are described as follows:

$$
\begin{aligned}
& \frac{\partial\left(k \overline{v_{i}}\right)}{\partial x_{j}}=\frac{\partial}{\partial x_{j}}\left[\left(\mu+\frac{\mu_{t}}{\sigma_{k}}\right) \frac{\partial k}{\partial x_{j}}\right]+G_{k}+G_{b}-\rho \varepsilon \\
& \frac{\partial\left(\varepsilon \overline{v_{i}}\right)}{\partial x_{j}}=\frac{\partial}{\partial x_{j}}\left[\left(\mu+\frac{\mu_{t}}{\sigma_{\varepsilon}}\right) \frac{\partial \varepsilon}{\partial x_{j}}\right]+\rho C_{1} S \varepsilon- \\
& -\rho C_{2} \frac{\varepsilon^{2}}{k+\sqrt{v \varepsilon}}+C_{1 \varepsilon} \frac{\varepsilon}{k} C_{3 \varepsilon} G_{b}
\end{aligned}
$$

where $G_{k}$ is the generation of turbulence kinetic energy due to the mean velocity gradients, $G_{b}$ is the generation of turbulence kinetic energy due to buoyancy, $\mu_{t}$ is turbulent viscosity, $\sigma_{k}$ and $\sigma_{\varepsilon}$ are respectively turbulent Prandtl numbers for $\mathrm{k}$ and $\varepsilon . C_{2}, C_{1 \varepsilon}$ and $C_{3 \varepsilon}$ are constants of turbulence model.

\subsection{Lagrangian phase}

Trajectory of particles is calculated by integrating the particle force balance equation, which is written in the reference frame:

$$
\begin{aligned}
& \frac{\mathrm{d} v_{p}}{\mathrm{dt}}=\frac{1}{\tau_{p}} \frac{C_{D} R e_{r}}{24}\left(v-v_{p}\right)+ \\
& +\left(\frac{\rho_{p}-\rho}{\rho_{p}}\right) g+F_{V M}+F_{L}
\end{aligned}
$$

where $v$ and $v_{p}$ are respectively the fluid and the particle velocity, $\rho_{p}$ is the particle density, $\operatorname{Re}_{r}$ is the relative Reynolds number defined as:

$$
R e_{r}=\frac{\rho d_{p}\left|v_{p}-v\right|}{\mu}
$$

$C_{D}=f\left(R e_{r}\right)$, the drag coefficient for smooth particles can be taken from:

$$
C_{D}=a_{1}+\frac{a_{2}}{R e_{r}}+\frac{a_{3}}{R e_{r}^{2}}
$$

where $a_{1}, a_{2}$ and $a_{3}$ are constants that apply over several ranges of $\mathrm{Re}_{\mathrm{r}}$ given by Morsi and Alexander [13]. 


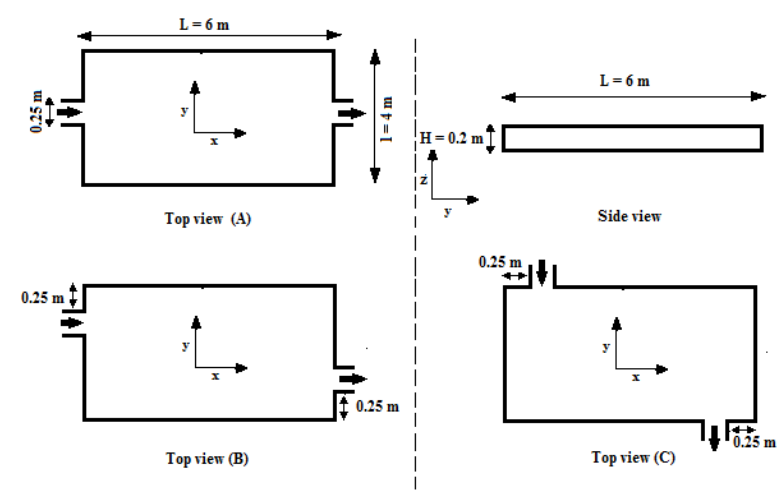

Figure 2. Schemes of standard tank geometries (A) and proposed modified geometries (B) and (C).

is the particle relaxation time, defines the velocity response time:

$$
\tau_{p}=\frac{\rho_{p} d_{p}^{2}}{18 \mu}
$$

The first term on the right hand side of equation (5) represents drag force per unit particle mass. The second is the buoyancy and gravity force.$F_{V M}$ represents the virtual mass, which is the force required to accelerate the fluid surrounding the particle and can be written as :

$$
F_{V M}=\frac{1}{2} \frac{\rho}{\rho_{p}} \frac{d}{d t}\left(v-v_{p}\right)
$$

$F_{L}$ is the lift force due to shear for small particle Reynolds numbers obtained by Saffman [14] and is expressed as follows :

$$
F_{L}=1,615 \rho v_{p}^{\frac{1}{2}} d_{p}^{2}\left|v_{p}-v\right|(\nabla \times v)^{\frac{1}{2}}
$$

The discrete phase is coupled with the Eulerian phase through momentum equation since there is a mutual effect between the flows of both phases. This momentum exchange is computed as:

$$
F_{M E}=\sum\left(\frac{1}{\tau_{p}} \frac{C_{D} \operatorname{Re}_{r}}{24}\left(v_{p}-v\right)+F_{\text {other }}\right) m_{p} \Delta t
$$

where: $\Delta_{t}$ is the time step and $F_{\text {other }}$ are the other interaction forces.

\subsection{Turbulent dispersion}

In order to account for turbulent dispersion of particles due to velocity fluctuation, a random walk model is used. The velocity fluctuation $v_{i}^{\prime}$ obeys a Gaussian probability, such that:

$$
v_{i}^{\prime}=\zeta \sqrt{\overline{v_{i}^{\prime 2}}}=\sqrt{\frac{2 k}{3}}
$$

where $\zeta$ is a normally distributed random number.

\section{THE CHARACTERISTICS OF THE TANKS}

\subsection{Grid independence study}

To simulate the flow behavior in the sedimentation tank, many computational fluid dynamics (CFD) programs are available. In this study, governing equations are solved by the commercial CFD code ANSYS Fluent. A grid independence study was performed to ensure the accuracy of the solution. The selected grid in this study was comprised of 344000 hexahedral elements.

The used discretization schemes were the SIMPLE for the pressure--velocity coupling that was developed by Patankar [15] and the second order upwind for the momentum, turbulence kinetic energy and dissipation rate of turbulence kinetic energy. Particles trajectories through the continuum phase are calculated using coupled discrete phase model (DPM). Particles are tracked and the flow field is recalculated in the presence of particles. The converged solution is determined when the absolute residuals normalized are below $10^{-4}$.

\subsection{Boundary conditions}

In this study, the initial condition for inlet and outlet are defined respectively as velocity magnitude normal to the inflow at $0.14 \mathrm{~m} / \mathrm{s}$ and pressure outlet. Symmetry condition for free surface was characterized by zero normal gradients. The solid boundaries are defined as stationary wall with no slip condition. Backflow conditions are taken for both inlet and outlet as: hydraulic diameter of $0.308 \mathrm{~m}$ and turbulence intensity of $4.21 \%$.

For the discrete phase model, additional boundary conditions are prescribed: "Escape" condition for inlet and outlet, this means particle will be escaped when it encounters the boundary in question. Trajectory calculations are terminated. "Trap" condition for bottom wall where particles will be settled. This means "trap" terminates the trajectory calculations and records the fate of the particle as "trapped". "Reflect" condition near solid boundaries. This means that the particle rebounds off the boundary in question with a change in its momentum as defined by the coefficient of restitution. This coefficient of restitution is equal to 1 if the particle retains all of its normal or tangential momentum after the rebound. A normal or tangential coefficient of restitution is equal to 0 if the particle retains none of its normal or tangential momentum after the rebound.

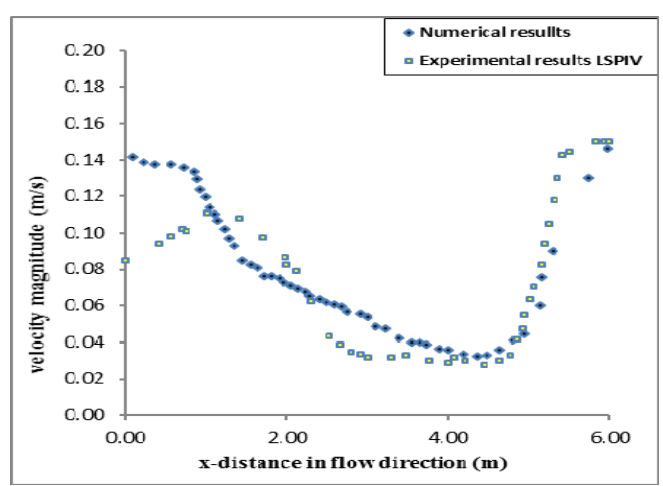

Figure3. Comparison of longitudinal velocity magnitude from numerical model (CFD) and Large-Scale-ParticleImage-Velocimetry (LSPIV) technique (A-case 1)

\subsection{Model validation}

To validate the numerical model, velocity magnitude at the basin centreline is compared with experimental results of Kantoush et al [12]. The experience consists 
in the development of Large Scale Particle Image Velocimetry (LSPIV) technique in order to measure velocity field in $2 \mathrm{D}$.

As can be seen in Fig 3, numerical results are in general in a good agreement with experimental data. However, at the interface between inlet channel and basin, a divergence between experimental data and numerical results may be observed: a sudden velocity
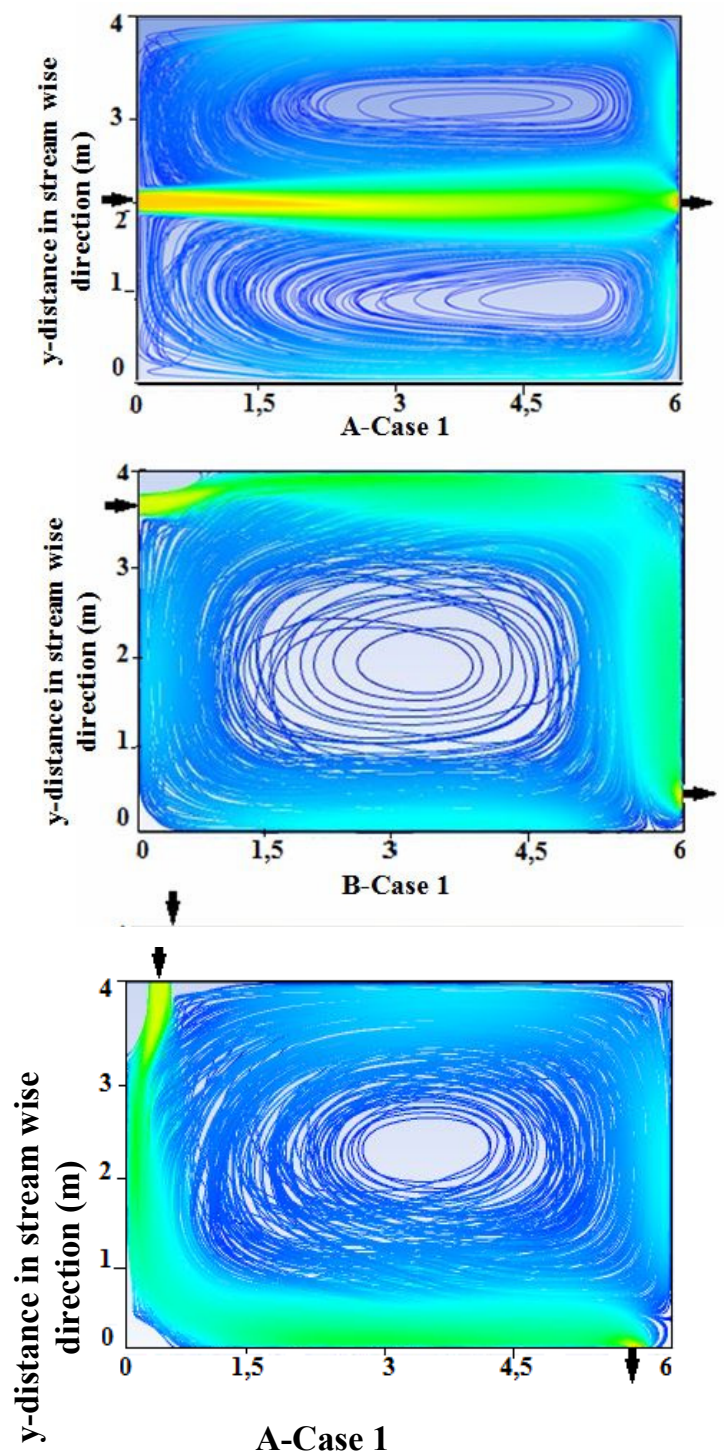

A-Case 1 increase followed by a gradual decrease throughout the whole basin length. The sudden increase in velocity might be due to the sudden influence of the recirculation eddy that produces significant shear between the jet and the stagnant water, influencing so the horizontal velocity distribution of the jet, before jet diffusion becomes more important [12]. For the same reason, the velocity magnitude drops from 2 to $4 \mathrm{~m}$ and rises from 4 to $6 \mathrm{~m}$.
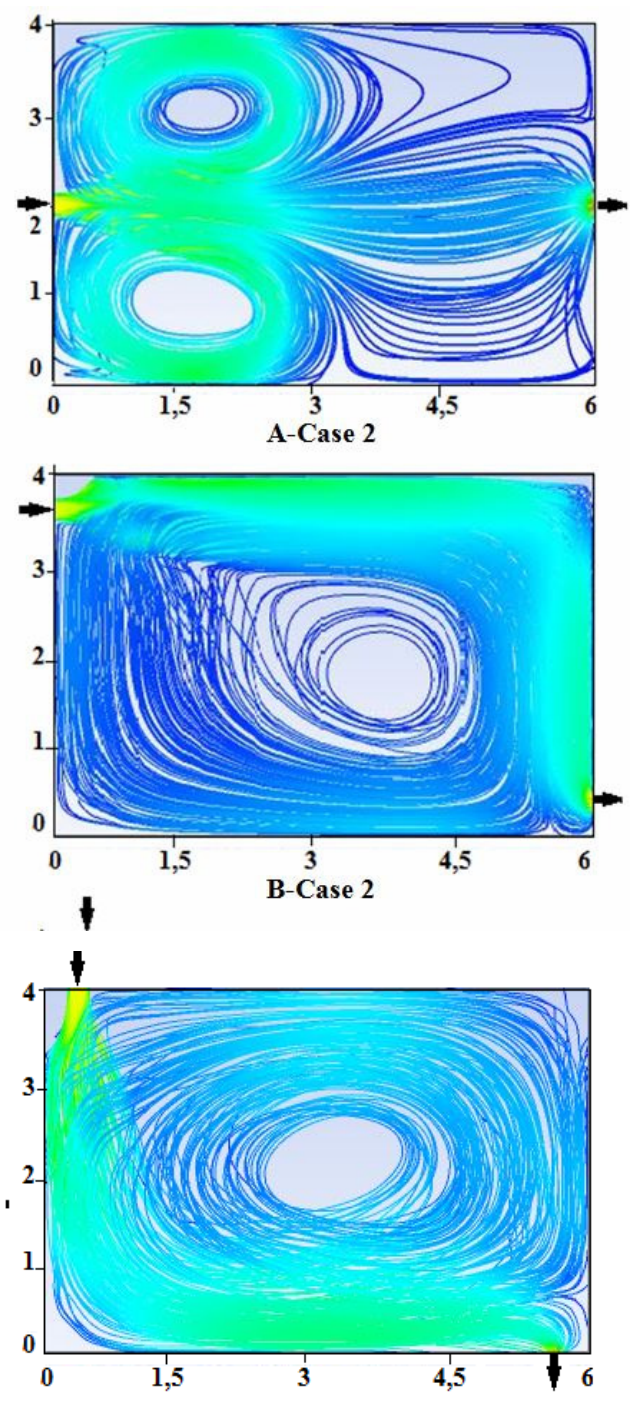

A-Case 2

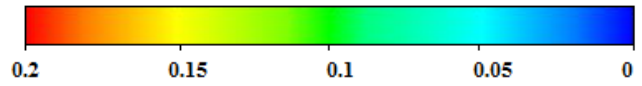

Figure 4: Top view of streamlines colored by velocity magnitude for standard geometry (A) and proposed modified geometries (B) and (C)
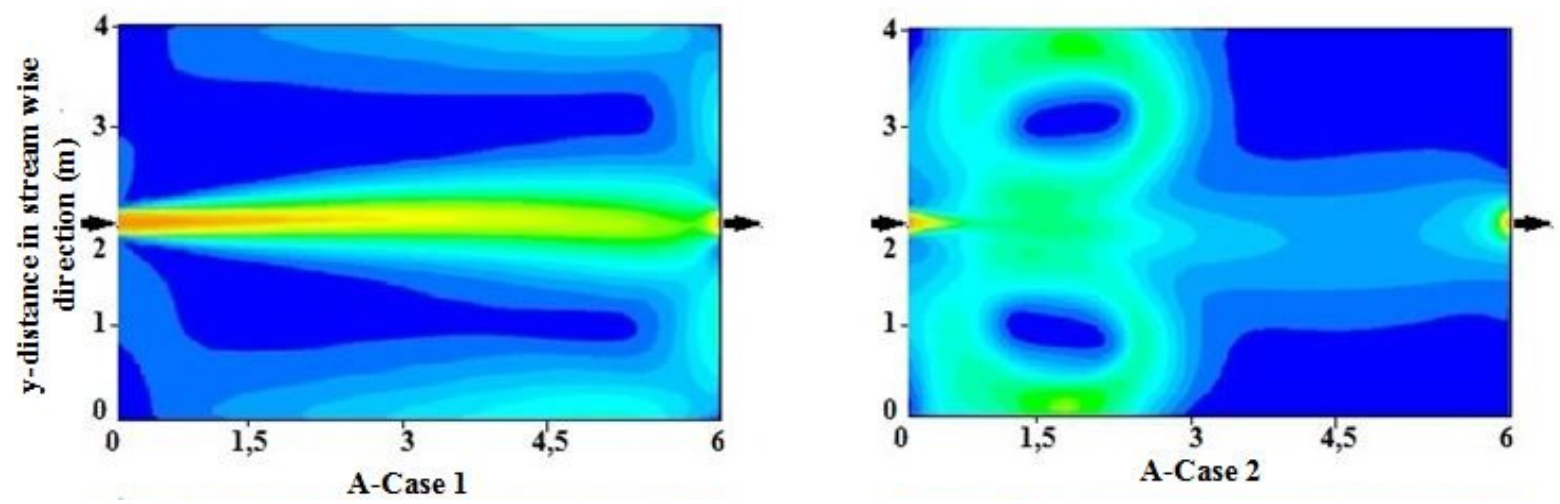

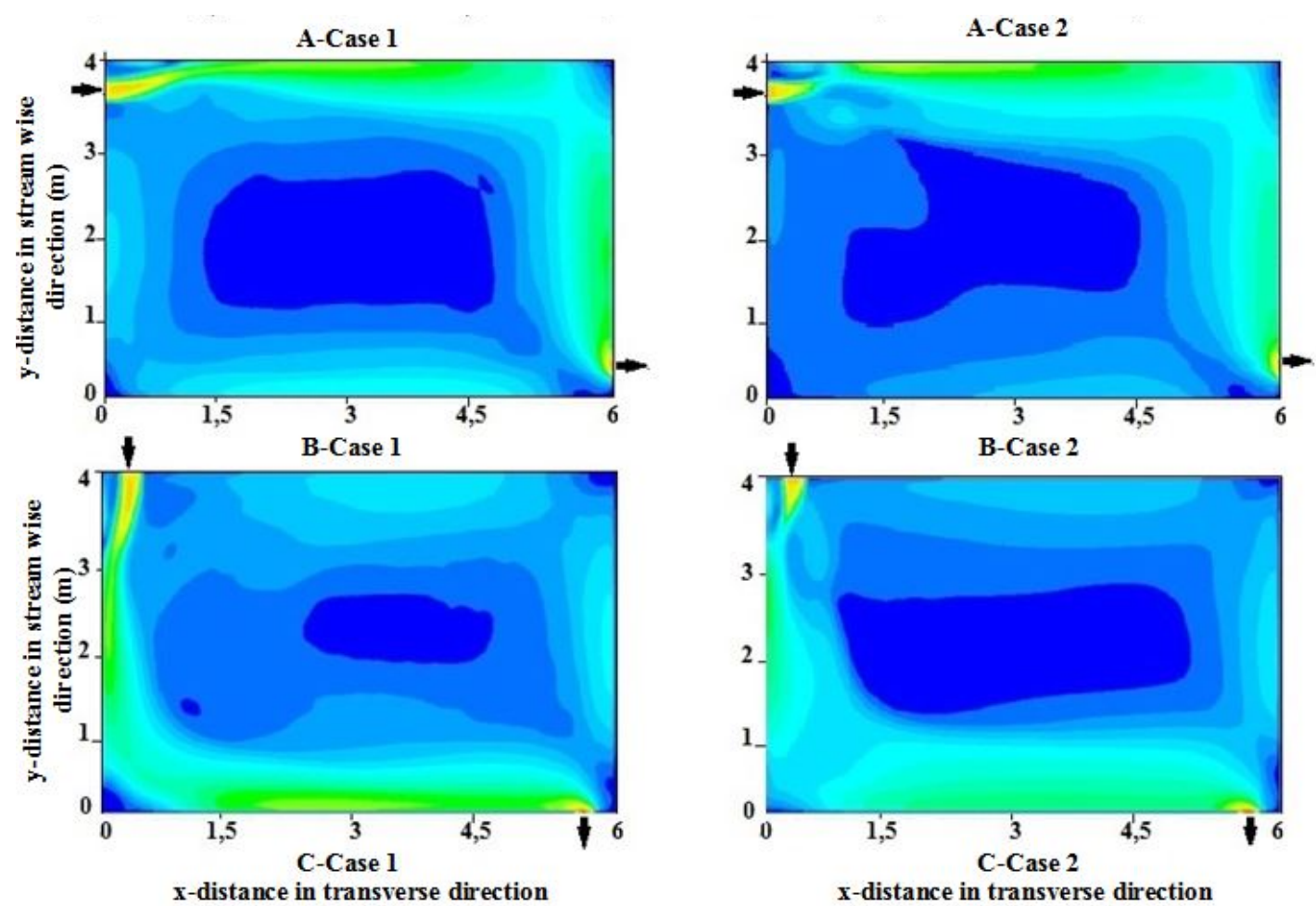

Figure 5: Top view of velocity contours for standard geometry (A) and proposed modified geometries (B) and (C)

\section{RESULTS AND DISCUSSION}

\subsection{Flow pattern}

The flow fields calculated for different inlet and outlet locations are shown in Fig 4. In the standard geometry (A), two recirculation large eddies appear and occupy a significant volume of the tank. The flow pattern is perfectly symmetric and differs from the experimental and numerical results shown in [12]. This symmetry which appears in the present paper has been observed by Kantoush et al [16] who used different turbulence closure schemes ( $k-\varepsilon$ and eddy viscosity models) to simulate the flow in shallow reservoir. It was found that only depth-average flow and sediment transport model (CCHE2D) is able to reproduce the strongly asymmetric flow observed during the experiments [12].

In the modified configurations ( $\mathrm{B}$ and $\mathrm{C}$ ), the fluid flow feed in the tank and spins around it is forming a large recirculation eddy.

On the other hand, when the sediment concentration increases, the flow field remains the same with case 1 except for the standard geometry (A), two small vortices appear.
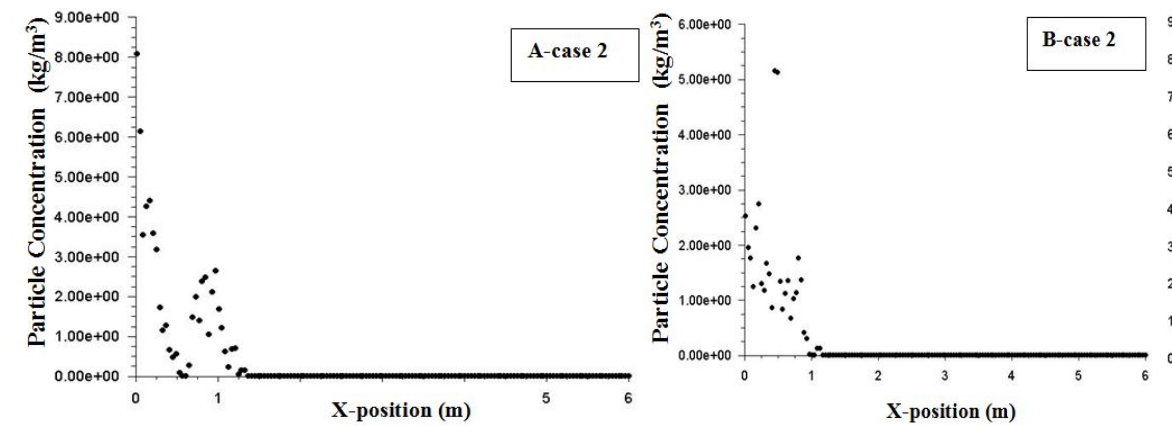

Figure 5 displayed velocity contours of standard and modified geometries. It can be seen that velocity attenuates near the wall, so that it allows particles to settle easily at the bottom. This phenomenon was the subject of various studies focused on the modelling of flow motion near to smooth and roughness wall [17].

\subsection{SOLIDS DISTRIBUTION}

Particles concentrations at the bottom for case 2 are depicted in Fig 6. It can be observed that all particles settle before leaving the tank for standard geometry (A) and modified geometries (B) and (C). That means, when sediments concentration increase to $10 \mathrm{~kg} / \mathrm{m}^{3}$, settling efficiency is not affected by inlet and outlet location of sedimentation tank.

In Fig. 7 particles distribution at the bottom for case 1 is illustrated. As it can be observed, the value of discrete phase concentration reached the bottom of the tank is very important along the main jet of the tank. Moreover, the modified geometries $\mathrm{B}$ and $\mathrm{C}$ allow sediment to settle at two sides of the tank. In fact, particle settling was enhanced near the wall. Furthermore, increasing particles concentration improves particles settling at the bottom.

Figure 6: Particles concentration $(\mathrm{kg} / \mathrm{m} 3)$ on the bottom of standard sedimentation tank (A) and proposed modified tank (B) and (C) for case 2 

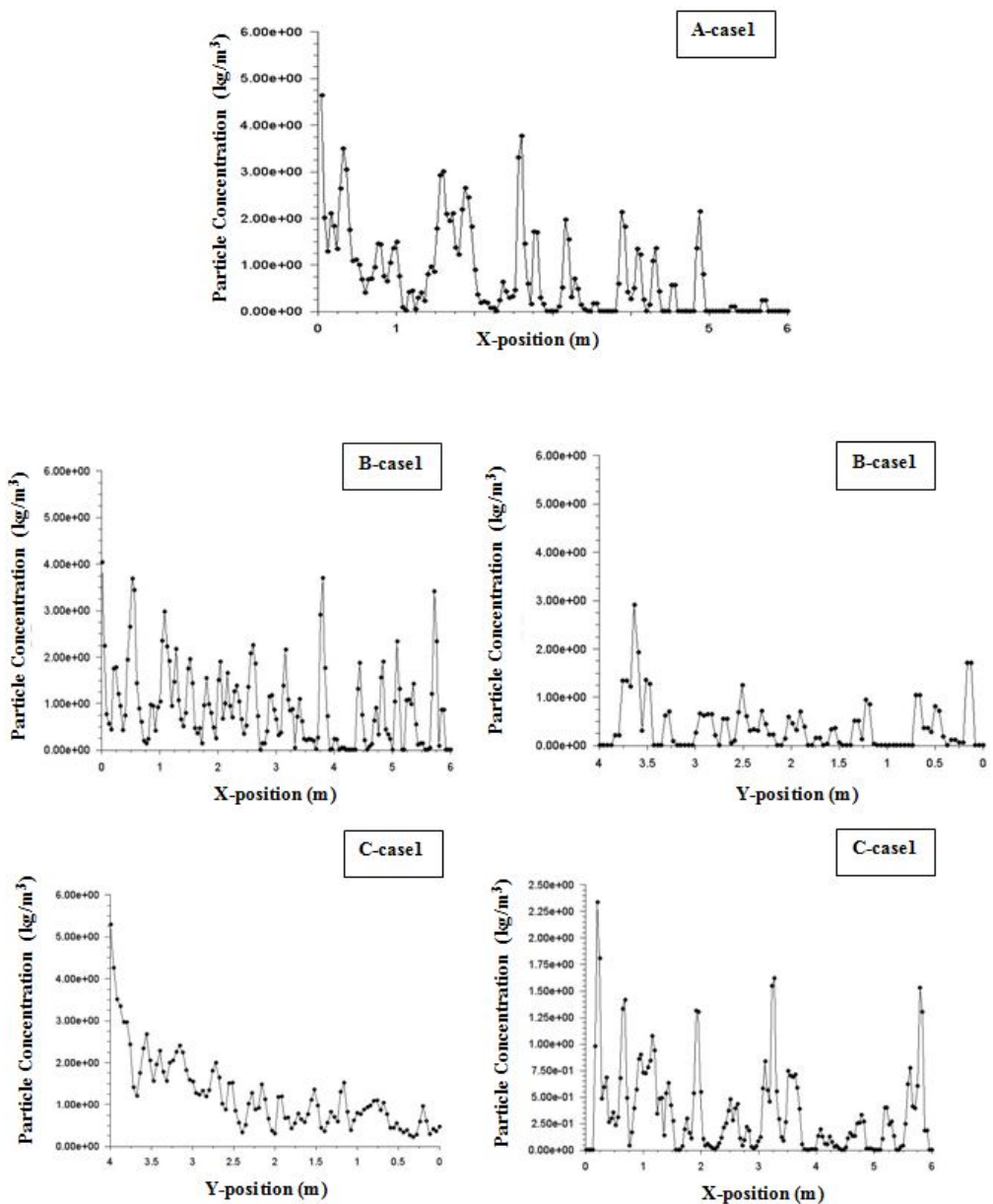

Figure 7: Sediments concentration $(\mathrm{kg} / \mathrm{m} 3)$ at the bottom of the tank for: A-case 1 , B- case 1 and C-case 1 along the flow direction

\subsection{TRAP EFFICIENCY}

In order to confirm the effect of inlet and outlet position on the removal efficiency, the total of sediment load deposited at the bottom of sedimentation tank is expressed in terms of trap efficiency defined as follows:

$$
T E=\frac{\mathrm{N}_{\text {trapped }}}{N_{\text {injected }}}
$$

where:

$\mathrm{N}_{\text {trapped }}$ : number of sediments trapped at the bottom. $\mathrm{N}_{\text {injected: }}$ : number of sediments injected in the inlet.

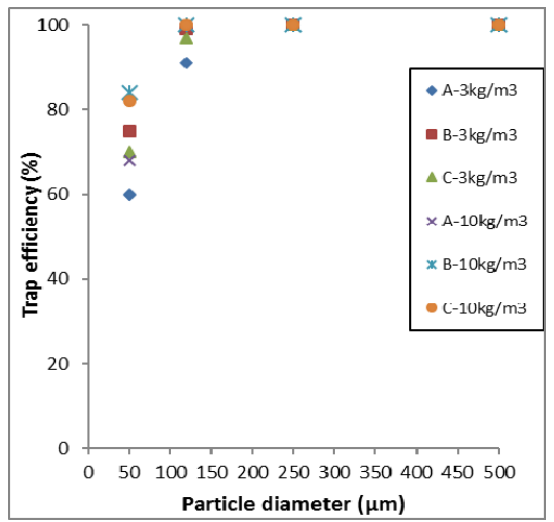

Figure 8: Trap efficiency of standard tank geometry $(A)$ and modified geometries $(B)$ and $(C)$ for different particle diameter and concentration
Trap efficiency of standard geometry A and modified goemetries $\mathrm{B}$ and $\mathrm{C}$ for each particle diameter and concentration is presented in Fig. 8 . It can be seen that trap efficiency increases with particle diameter and concentration.

Moreover, for small particles $(50,120 \mu \mathrm{m})$, modified geometry B is the best in terms of trap efficiency. However, when particle diameter is greater than $250 \mu \mathrm{m}$, trap efficiency remains the same for different geometries and particle concentration.

\section{CONCLUSION}

In the present paper, numerical simulations are performed for different particle diameter and sediment concentration. Two different tanks geometries have been tested as well as the standard geometry. It was found that changing inlet and outlet location of the tank can have a considerable effect on flow pattern. In fact, trap efficiency has been improved for the proposed modified geometries B and C, especially for small particles $(50,120 \mu \mathrm{m})$. Nevertheless, when particles diameter and concentration increase, trap efficiency tends to be the same for all geometries.

Finally, the proposed modified geometries improve hydraulic efficiency, i.e., water resides more on the tank, and consequently particles have sufficient time to settle at the bottom. Moreover, the flow near the wall enhances the settling of sediment. 


\section{REFERENCES}

[1] Nakayama, F. S. et Bucks, D. A.: Water quality in drip/trickle irrigation: a review, Irrig. Sci. Vol. 12, No. 4, pp. 187-192, 1991.

[2] Franz, K., Prenner, M..: DEM - Simulation of Conveyor Transfer Chutes, FME Transaction, Vol. 37, No 4, pp. 185-195, 2009.

[3] Jeli, Z. M., Stojicevic, I., Cvetkovic, A., Duta, et D.L. Popa..: A 3D analysis of geometrical factors and their influence on air flow around a satellite dish, FME Trans., Vol. 45, No 2, pp. 262-267, 2017.

[4] Larsen, P.: On the hydraulics of rectangular settling basins, Report No. 1001, Department of Water Research Engineering, Lund Institute of Technology, Lund, Sweden, 1977.

[5] Imam, E. et al.: Numerical modeling of sedimentation tanks, ASCE- J. Hydr. Eng. Vol.109, No. 12, pp. 1740-1754, 1983.

[6] Schamber, D. R., Larock, B. E..: Numerical analysis of flow in sedimentation basins, J. Hydraul. Div. Vol.107, No 5, pp. 575-591, 1981.

[7] Huggins, D. L. et al.: Analysis of sediment transport modeling using computational fluid dynamics (CFD) for aquaculture raceways. Aquac. Eng. No 31, pp. 277-293, 2004.

[8] Goula, A.M., Kostoglou, M., Karapantsios, T.D., Zouboulis, A.I..: A CFD methodology for the design of sedimentation tanks in potable water treatment case study: the influence of a feed flow control baffle, Chem. Eng. J. Vol. 140, pp. 110 121, 2008.

[9] Ahmed, F. H., Kamel, A. and Abdel Jawad, S.: Experimental determination of the optimal location and contraction of sedimentation tank baffles, J. Water Air Soil Pollut., Vol.92, pp. 251-271, 1996.

[10] Bajcar, T., Steinman, F., Širok, B., and Prešeren, T..: Sedimentation efficiency of two continuously operating circular settling tanks with different inlet-and outlet arrangements, J. Chem. Eng. Vol. 178, pp. 217-224, 2011

[11] Rostami, F., Shahrokhi, M., Md Said, M. A., Abdullah, R. and Syafalni..: Numerical modeling on inlet aperture effects on flow pattern in primary settling tanks, Appl. Math. Model. Vol. 35. No 6, pp. 3012-3020, 2011.

[12] Kantoush, S.A., Bollaert, E., De Cesare, G., Boillat, J.L. and Schleiss, A.: Flow Field
Investigation in a Rectangular Shallow Reservoir using UVP, LSPIV and numerical model, in: proceeding of the Fifth International Symposium on Ultrasonic Doppler Methods for Fluid Mechanics and Fluid Engineering, 12-14.09.2006, ETH Zurich, Switzerland, pp. 129-133.

[13] Morsi, S.A., Alexander, A.J.: An Investigation of Particle Trajectories in Two-Phase Flow Systems, J. Fluid Mech. Vol. 55, No. 2, pp. 193-208, 1972.

[14] Saffman, P. G.: The Lift on a Small Sphere in a Slow Shear Flow, J. Fluid Mech., vol. 30, pp. 385400, 1965.

[15] Patankar, S..: Numerical heat transfer and fluid flow, McGraw-Hill Book Company, New York, 1980.

[16] Kantoush, S.A., Bollaert, E., and Schleiss, A.: Experimental and numerical modelling of sedimentation in a rectangular shallow basin, J. International Journal of Sediment Research, Vol. 23, No. 3, pp. 212-232, 2008.

[17] Assoudi, R., Lamzoud, K., Chaoui, M.: Influence of the Wall Roughness on a Linear Shear Flow, FME Transactions, Vol. 46, No 2, pp. 272-277, 2018.

\section{ПОБОЉШАЫЕ ЕФИКАСНОСТИ СЕДИМЕН- \\ ТАЦИОНИХ РЕЗЕРВОАРА У УКЛАЪАҢУ ТАЛОГА КОРИШЋЕЊЕМ РАЗЛИЧИТОГ УЛАЗНОГ И ИЗЛАЗНОГ ПОЛОЖАЈА}

\section{Ф.Буисфи, А, Буисфи, Х. Кариш, М. Ел Бухали, М. Чауи}

Таложење гравитацијом је најстарији начин пречишћавања воде. Улазни и излазни правоугаони седиментациони резервоар се често постављају на средини резервоара. Рад истражује утицај промене положаја улазног и излазног правоугаоног резервоара на ефикасност уклањања талога коришћењем метода Рачунарске динамике флуида. Предлажу се две различите конфигурације а испитивање је извршено са честицама различитог пречника и концентрације. Експериментални подаци потврђују могућности нумеричког модела да опише понашање поља протока у резервоару. Резултати показују да улазни и излазни положај имају утицаја на поље протока и ефикасност уклањања талога из резервоара, нарочито у случају финих честица (50 и $120 \mu \mathrm{m})$. 